\title{
The Yoruba's Cultural Perspective of Death with Special Reference to Twins
}

\author{
Taiwo O. Olaleye-Oruene \\ The Olabisi Olaleye Foundation
}

\begin{abstract}
To the Yoruba people of South-West Nigeria, on the West Coast of Africa, death, or transition from one level of existence to another, is well accepted as part of life. Rites of passage are seen as an opportunity for saying farewell to the deceased and seeking their continuous protection of the living members of the families. After the death of a twin, a twin statuette, symbolically representing the departed twin, also acts as a companion and solace to the living twin. This paper examines these subjects including the special rites performed for twins, the relationship of the family to the deceased and the question of reincarnation
\end{abstract}

\section{Meaning of Death}

Death-Ikú according to Bolaji Idowu (1962) is the agent the Yoruba believe to be responsible, under commission from Olodumare (God), for killing and removing people from this earth. Hence he is known as Ojisé Orun Heaven's Bailiff — and "dying" is described as a "debt" which everyone has to pay, sooner or later. This finality and inevitability is reflected in different adages:

Arùn l'a’wò, a kì 'wo ikú — "Sickness can be healed, death cannot". In other words, sickness can be treated with medicine but not so death. An Odu recitation from the belief system of Òrunmilà says:

Ikú ìbá gb’owó,
Owó l'à bá san;
Ojisé Òrun kì'gb'owó
If Ikú would accept ransom,
It is ransom we would have paid;
Heaven's bailiff does not accept ransom. (Idowu, 1962 p. 186).

The Yoruba believe that the death of a young person is a tragedy demanding mourning. But the passing of an elderly person is an occasion for rejoicing and his offspring perform the funeral rites. But whether of the young or old, death in the Yoruba belief system is not an end of life but only a means whereby the present earthly existence is changed for another, that of Èhìn-İwà — the "After-life" which is superior to the present.

\section{Funeral Rites of Passage}

The funeral rites of passage vary but all show the deceased as making a journey. Thus, the first rite of killing a fowl is intended to make the journey easy. When the departed is laid in state, a yam meal is prepared and, in the case of twins, this includes beans. The deceased's portion is placed at the foot of the bier and, during the burial, the relatives bring gifts including clothes, fowls and animals. The deceased is wrapped in all the clothes forming the wardrobe for the next life. Prayers to the deceased ask that he does not sleep in heaven but rather keep a watchful eye over his children.

Several days after the burial, another rite, performed by night, is called — "Bringing the spirit of the deceased into the house". This is to forge an intimate intercourse with the deceased, who now assumes the role of an ancestor. These have been released from all earthly restraints and have limitless potentialities for the benefit or detriment of those who still live on earth. The Yoruba believe that the deceased are never really in the grave and, have not renounced any parental functions or control over their survivors (Idowu, 1962, p. 189).

Like the saints in Western belief system, the ancestors are venerated and ceremonies are performed annually. Moreover, they are regarded as participating members of the family and community and are remembered every day at meal times. A shrine is set up in or by the house where the offspring may make offerings, beg special favours, enter into covenants with one another or swear over bones of contention. The communication with ancestors is also apparent in the Yoruba belief that the deceased can be seen in dreams or trances and provide advice or instruction about family predicaments. They can also send messages. This communion is seen as a manifestation of an unbroken family relationship between the parent and offspring.

\section{Transition of Twins}

Twins or 'ibeji' as they are generically called irrespective of their sex, are regarded as very special children by the Yoruba people. (Incidentally, the twinning rate amongst the Yoruba is probably the highest in the world and the second twin to arrive, Kehinde, is commonly considered the senior one: the first born, Taiwo, sees that the way is clear for him or her).

Their importance is shown by the fact that their birthdays are celebrated on a weekly basis with special foodstuffs

Address for correspondence: Taiwo O. Olaleye-Oruene, Flat 44, Collingwood House, 99, New Cavendish Street, London W1M 7FQ 
which include beans, palm oil, pumpkin and various fruits, especially, bananas. The beans signify multiplicity. The palm oil is to cool the temperamental nature of the twins. Twins are associated with the Colombus monkeys (which also have multiple births) whose main diet are fruits notably bananas. Thus fruits are incorporated into the ceremony of twins birth.

Twins are never said to have died, but to have travelled abroad or "gone to the market". This could help to avoid distressing the living twin who could otherwise pine to death. When a twin takes leave of this world, a commemorative statuette is commissioned, called the "ibeji". This statuette keeps company with the earthly twin and acts as a playmate just like a favourite doll. It is treated in exactly the same way as the living twin, that is, fed, bathed, clothed and carried around right through adulthood. The Ibeji is seen as the deceased twin's representative who keeps the living twin alive (Oruene, 1983). As a twin herself, the author had a twin statuette commissioned for her twin sister who had passed into the world beyond. Unfortunately, the statuette was stolen in 1986. All attempts to recover the ibeji have so far been fruitless. For a Yoruba the loss of a twin sister and the theft of the ibeji is a double tragedy.

\section{$\overline{\text { Reincarnation }}$}

Death is perceived as part of a cycle of life in which the deceased is seen as an ancestor but one who could be reincarnated, that is, reborn, in a new member of the family. A man becomes an earthly being, crosses over into the realm of the spirits or ancestors, and then returns, reincarnated into the earthly realm in a neonate of the family. Hence, soon after the death of a grandparent, the offspring born immediately, if female is called "Yétúndé" — "Mama returns" and if male is called "Bàbátúndè" — "Father returns". The deceased grandparent has been reborn in a new member of the family (Idowu, 1962).

\section{Conclusion}

In the Yoruba culture, death is perceived as the norm but joy or sorrow depends on the age of the deceased. In that realm of the spirits, the departed soul is treated as an ancestor and entreated for favours and protection. After the death of a twin, a twin statuette is commissioned which represents him or her and simultaneously pacifies the earthly twin. The spirit existence is however not permanent because the soul of the departed can be reincarnated through a newborn member of the family.

\section{References}

Idowu, B. E. (1962). Olodumare: God in Yoruba belief. San Francisco: Longman.

Oruene, T. O. (1983). Cultic powers of Yoruba twins: Manifestaion of traditional religion of the Yoruba. Acta Geneticae Medicae et Gemellologiae, 32, 221-228.

\section{$\overline{\text { Further Reading }}$}

Johnson, S. (1937). The history of the Yoruba. Lagos: CMS Bookshop.

Kenyo, E. A. (1953). Isedale Yoruba. Lagos: CMS Press

Lucas, J. O. (1948). The religion of the Yoruba. Lagos: CMS Press

Talbot, P. A. (1926). The peoples of Southern Nigeria. Oxford: Oxford University Press. 